\title{
Taxonomic characterisation of Pseudomonas strain L48 and formal proposal of Pseudomonas entomophila sp. nov. मै
}

\author{
Magdalena Mulet ${ }^{a}$, Margarita Gomila ${ }^{c}$, Bruno Lemaitre ${ }^{\mathrm{d}}$, Jorge Lalucat ${ }^{\mathrm{a}, \mathrm{b}}$, Elena García-Valdés ${ }^{\mathrm{a}, \mathrm{b}, *}$ \\ a Microbiologia, Departament de Biologia, Edifici Guillem Colom, Universitat de les Illes Balears, Campus UIB, 07122 Palma de Mallorca, Spain \\ b Institut Mediterrani d'Estudis Avançats (IMEDEA, CSIC-UIB), Campus UIB, 07122 Palma de Mallorca, Spain \\ c Unidad de Investigación, Microbiología, Fundación Hospital Son Llàtzer, 07198 Palma de Mallorca, Islas Baleares, Spain \\ d EPFL, Ecole Polytechnique Federale de Lausanne, School of Life Sciences, Global Health Institute, Station 15, CH-1015 Lausanne, Switzerland
}

\section{A R T I C L E I N F O}

\section{Article history:}

Received 16 August 2011

Received in revised form 9 December 2011

Accepted 9 December 2011

\section{Keywords:}

Pseudomonas entomophila sp. nov.

Bacteria

Taxonomy

\begin{abstract}
A B S T R A C T
An entomopathogenic, Gram-negative bacterium isolated from a female specimen of the fruit fly Drosophila melanogaster was taxonomically characterised. Strain $\mathrm{L}^{\mathrm{T}} \mathrm{S}^{\mathrm{T}}$ was strictly aerobic, nonfermentative, oxidase and catalase positive, rod-shaped, and motile due to a polar inserted flagellum. Phylogenetic analysis of the $16 \mathrm{~S}$ rRNA gene and three other housekeeping genes placed strain $\mathrm{L} 48^{\mathrm{T}}$ in the Pseudomonas putida phylogenetic group. DNA-DNA hybridisation studies together with phenotypic metabolic tests and MALDI-TOF MS analysis justified the proposal of strain $\mathrm{L}^{\mathrm{T}} \mathrm{S}^{\mathrm{T}}$ as a representative of a novel species, for which the name Pseudomonas entomophila sp. nov. is proposed. The type strain is deposited in culture collections under accession numbers CCUG $61470^{\mathrm{T}}$ and CECT $7985^{\mathrm{T}}$.
\end{abstract}

(c) 2012 Elsevier GmbH. All rights reserved.
Bacterial strain $\mathrm{L} 8^{\mathrm{T}}$ was isolated from a female specimen of the fruit fly Drosophila melanogaster, collected at Calvaire, (Guadeloupe Island). It was previously described as an entomopathogenic bacterium by Vodovar et al. [27]. Since its first description, numerous studies on strain $\mathrm{L} 48^{\mathrm{T}}$ have focused on its pathogenicity [24], siderophore production [13] and on genomic and proteomic analysis. Its genome has been completely sequenced, showing a total of 5.888.780 nt [26]. The comparison of the 16S rRNA gene sequence in the databases indicated that strain $\mathrm{L}^{\mathrm{T}} \mathrm{S}^{\mathrm{T}}$ belongs to the Pseudomonas genus. The three dendrograms deduced from protein coding genes ( $r p o D$ and gyrB) and the 16S rRNA gene sequences indicated that strain $\mathrm{L}^{\mathrm{T}} 8^{\mathrm{T}}$ is closely related to Pseudomonas monteilii and Pseudomonas mosselii species [27]. Because strain $\mathrm{L}^{\mathrm{T}} \mathrm{T}^{\mathrm{T}}$ represented an uncharacterised Pseudomonas species with some unique entomopathogenic properties, Vodovar and collaborators

\footnotetext{
is The GenBank/EMBL/DDBJ accession numbers for the nucleotide sequences reported in this study are: HE577792 (strain P. alkylphenolia JCM 16553 gyrB gene), HE577794 (strain P. alkylphenolia JCM 16553 rpoD gene), HE577798 (strain $P$. alkylphenolia JCM 16553 rpoB gene), HE577795 (strain P. japonica JCM $21532^{\mathrm{T}}$ rpoD gene), HE577800 (strain P. japonica JCM $21532^{\mathrm{T}}$ rpoB gene), HE577796 (strain P. taiwanensis DSM $21245^{\mathrm{T}}$ rpoD gene), HE577797 (strain $P$. taiwanensis DSM $21245^{\mathrm{T}} \mathrm{rpoB}$ gene), HE577791 (strain $P$. vranovensis DSM $16006^{\mathrm{T}}$ gyrB gene), HE577793 (strain P. vranovensis DSM $16006^{\mathrm{T}}$ rpoD), and HE577799 (strain P. vranovensis DSM $16006^{\mathrm{T}}$ rpoB gene).

* Corresponding author at: Microbiologia, Departament de Biologia, Edifici Guillem Colom, Universitat de les Illes Balears, Crtra. de Valldemosa Km 7,5, 07122 Palma de Mallorca, Spain. Tel.: +34 971 173141; fax: +34 971173184.

E-mail address: elena.garciavaldes@uib.es (E. García-Valdés).
}

designated it Pseudomonas entomophila [27]. However, it has not yet been formally described as a new species and has no standing in the nomenclature. The relevant pathogenic characteristics together with their metabolic versatility warrants a complete taxonomic study in order to consider P. entomophila a novel Pseudomonas species, with strain $248^{\mathrm{T}}$ as the type strain. It was deposited in two culture collections under accession numbers CCUG $61470^{\mathrm{T}}$ and CECT $7985^{\mathrm{T}}$.

The type strains of all species in the Pseudomonas putida phylogenetic group, as defined in Mulet et al. [14], were included in the present study (Supplementary Table S1). Pseudomonas alkylphenolia JCM 16553 [25] belongs phylogenetically to this group. It has no standing in the nomenclature, but was also included. The strains were routinely cultured at $30^{\circ} \mathrm{C}$ on LB medium.

For phylogenetic analysis, methods previously described in Mulet et al. [14] were used for DNA extraction, amplification and sequencing by polymerase chain reaction. Primers and accession numbers of sequences used in the analysis are shown in Supplementary Tables S2 and S3 [11,15,19,21,22,29]. A series of individual trees from the 16S rRNA, gyrase beta subunit (gyrB), beta subunit of the RNA polymerase $(r p o B)$ and RNA polymerase 70 sigma factor $(r p o D)$ partial genes as well as concatenated gene tree of these four genes were constructed as described in Mulet et al. $[14,16]$ and are presented in Fig. 1 and Supplementary Fig. S1. The 16S rRNA, gyrB, rpoB and $r p o D$ gene sequences of $P$. entomophila $\mathrm{L}_{4} 8^{\mathrm{T}}$ were retrieved from the National Center for Biotechnology Information (NCBI) database (www.ncbi.nlm.nih.gov/) from the genome sequence (NC_008027) [26]. Jukes-Cantor (JC) [7], maximum likelihood (ML) [5] and maximum parsimony (MP) [17] 


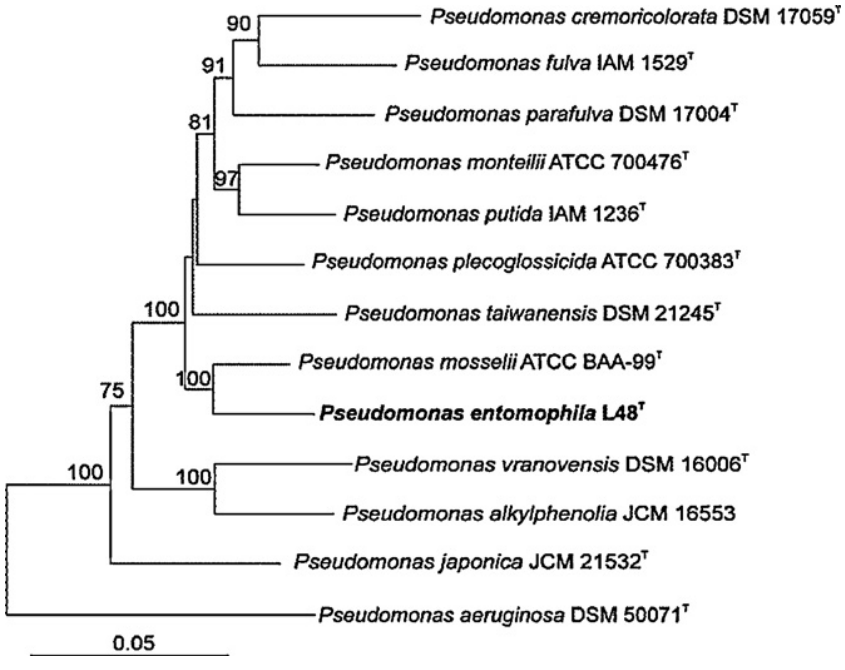

Fig. 1. Phylogenetic tree of Pseudomonas entomophila $\mathrm{L} 48^{\mathrm{T}}$ and phylogenetically close members of Pseudomonas based on the analysis of four concatenated genes (16S rRNA, gyrB, rpoD and $r p o B ; 3723 \mathrm{nt}$ ). Distance matrix was calculated by the Jukes-Cantor method. Dendrograms were generated by the neighbour-joining method. P. aeruginosa DSM $50071^{\mathrm{T}}$ was used as outgroup. The bar indicates sequence divergence. Percentage bootstrap values of more than $70 \%$ (from 1000 replicates) are indicated at the nodes.

algorithms were used for comparison. P. entomophila $\mathrm{L} 48^{\mathrm{T}}$ was always located in a separate branch in the $P$. putida group. The lowest 16S rRNA gene similarity within the group was $97.04 \%$ for Pseudomonas vranovensis DSM $16006^{\mathrm{T}}$ and Pseudomonas fulva IAM $1529^{\mathrm{T}}$, and the highest similarity was $99.84 \%$ between Pseudomonas monteilli ATTC $700476^{\mathrm{T}}$, Pseudomonas taiwanensis DSM $17004^{\mathrm{T}}$ and Pseudomonas plecoglossicida ATCC $700383^{\mathrm{T}}$ (Supplementary Table S4). Pseudomonas mosselli ATCC BAA-99 ${ }^{\mathrm{T}}$ was the closest type strain to $P$. entomophila $\mathrm{L}^{4} 8^{\mathrm{T}}$ ( $99.76 \%$ similarity).

The usefulness of the multilocus sequence analysis (MLSA) of four concatenated genes has been demonstrated previously [14]. A total of $3723 \mathrm{nt}$ from the 4 genes studied (16S rDNA, gyrB, rpoD and $r p o B$ ) of the type strains of the species in the P. putida group, have been aligned and concatenated. The neighbour-joining tree (Fig. 1) obtained after applying the Jukes-Cantor algorithm indicated that the closest strain to $P$. entomophila $\mathrm{L}^{2} 8^{\mathrm{T}}$ is $P$. mosselii ATCC BAA$99^{\mathrm{T}}$ (95.55\% similarity). The distance with Pseudomonas aeruginosa DSM $50071^{\mathrm{T}}$, which is the type species of the Pseudomonas genus, was $84.73 \%$. The intragroup mean value for members of the P. putida group was calculated to be $92.73 \pm 3.42 \%$, and $91.19 \%$ the minimum similarity between species. Mulet et al. [14] established a similarity of $97 \%$ in the MLSA of these four genes as the threshold value for strains in the same species in the genus Pseudomonas. The $95.55 \%$ similarity obtained between $P$. entomophila $\mathrm{L} 48^{\mathrm{T}}$ and $P$. mosselli ATCC BAA- $99^{\mathrm{T}}$ indicated that $P$. entomophila $\mathrm{L} 48^{\mathrm{T}}$ is a member of the $P$. putida group, although it cannot be ascribed phylogenetically to any of the known Pseudomonas species.

The P. entomophila $\mathrm{L}^{4} 8^{\mathrm{T}}$ chromosome has 5.888 .780 nucleotides with a $\mathrm{G}+\mathrm{C}$ content, deduced from the whole chromosome sequence, of $60 \mathrm{~mol} \%$ [26]. Compared to the other $20 \mathrm{Pseu}$ domonas known genomes, it has an intermediate size; chromosome sizes in Pseudomonas species range from $4.56 \mathrm{Mb}$ in P. stutzeri A1501 to $7.14 \mathrm{Mb}$ for Pseudomonas fluorescens Pf5 (ftp://ftp.ncbi.nlm.nih.gov/genomes/). The Average Nucleotide Identity (ANIb) [6] within members of the genus was calculated previously, indicating that $P$. entomophila $\mathrm{L}_{4} 8^{\mathrm{T}}$ is related to members of the $P$. putida group, but not to other species in the genus [14].

DNA-DNA hybridisation experiments were performed in duplicate using a method described by Lind and Ursing [12], modified by Ziemke et al. [30]. Reference DNA from strain $\mathrm{L}^{2}{ }^{\mathrm{T}}, P$. mosselii and $P$. putida type strains was double-labelled with DIG-1-dUTP and biotin-16-dUTP using a nick translation kit (Boehringer Mannheim). Labelled DNAs were hybridised separately with DNAs from the other type strains (Table 1 ). The reassociation temperature was $69.3^{\circ} \mathrm{C}$. DNA relatedness is reported as the average percent reassociation relative to the reassociation of the probe DNA to itself. The highest value was obtained in the hybridisation between $P$. entomophila $\mathrm{L}^{2} 8^{\mathrm{T}}$ and $P$. putida IAM $1529^{\mathrm{T}}$ and was $51 \%$, which is clearly below the accepted species threshold of $70 \%$, confirming that strain $P$. entomophila $\mathrm{L}_{4} 8^{\mathrm{T}}$ was genomically distinct to the type strains of all species within the group.

Morphologically, P. entomophila $\mathrm{L}^{4} 8^{\mathrm{T}}$ cells were rod shaped (0.67-1.0 $\mu \mathrm{m}$ wide and $2.2 \mu \mathrm{m}$ long), motile by means of one polar inserted flagellum (Supplementary Fig. S2) [10] and stained Gram negative following Cowan's method [2]. After incubation for $16 \mathrm{~h}$ at $30^{\circ} \mathrm{C}$ on LB plates, colonies were circular, beige in colour, flat, with regular edges and approximately $3-4 \mathrm{~mm}$ in diameter.

P. entomophila $\mathrm{L} 48^{\mathrm{T}}$ was able to grow in LB medium at $4{ }^{\circ} \mathrm{C}$, $15^{\circ} \mathrm{C}, 20^{\circ} \mathrm{C}, 30^{\circ} \mathrm{C}$ and $37^{\circ} \mathrm{C}$ in $24 \mathrm{~h}$ and showed a slow growth at $42{ }^{\circ} \mathrm{C}$ after $36 \mathrm{~h}$ incubation. However, no growth was detected at $46^{\circ} \mathrm{C}$ or $50^{\circ} \mathrm{C}$. Growth was observed on Nutrient Broth (Merck) in the presence of $0-6 \%(\mathrm{w} / \mathrm{v}) \mathrm{NaCl}$ (optimum at $2-3 \%$ ) and tolerated $\mathrm{pH}$ ranging from 3-10 (optimum at 5-9). The oxidase

Table 1

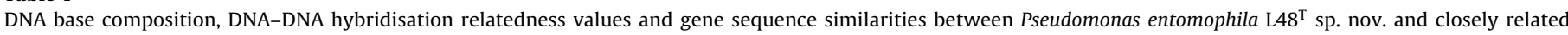
Pseudomonas species.

\begin{tabular}{|c|c|c|c|c|c|c|}
\hline \multirow[t]{2}{*}{ Bacterial strains } & \multirow[t]{2}{*}{$\begin{array}{l}\mathrm{G}+\mathrm{C} \\
\text { content } \\
(\mathrm{mol} \%)\end{array}$} & \multicolumn{3}{|c|}{ Reassociation $(\%)^{\mathrm{b}}$ with labelled DNA from } & \multicolumn{2}{|c|}{$\begin{array}{l}\text { Gene sequence } \\
\text { similarities (\%) with } \\
\text { respect to strain } \mathrm{L}^{\mathrm{T}}{ }^{\mathrm{T}}\end{array}$} \\
\hline & & P. entomophila $\mathrm{L}_{4} 8^{\mathrm{T}}$ & P. mosselii ATCC BAA-99 ${ }^{\mathrm{T}}$ & P. putida IAM $1236^{\mathrm{T}}$ & 16S rRNA & MLSA \\
\hline P. entomophila $\mathrm{L} 48^{\mathrm{T}}$ & 60 & 100 & 48 & 51 & 100 & 100 \\
\hline P. cremoricolorata DSM $17059^{\mathrm{T}}$ & $62^{\mathrm{a}}$ & 18 & 32 & 28 & 98.7 & 91.2 \\
\hline P. fulva IAM $1529^{\mathrm{T}}$ & $60^{\mathrm{a}}$ & 18 & 35 & 35 & 98.3 & 91.0 \\
\hline P. monteilii ATCC $700476^{\mathrm{T}}$ & $61^{\mathrm{a}}$ & 23 & 45 & 46 & 99.7 & 93.2 \\
\hline P. mosselii ATCC BAA- $99^{\mathrm{T}}$ & $63^{a}$ & 27 & 100 & 23 & 99.8 & 95.5 \\
\hline P. parafulva DSM $17004^{\mathrm{T}}$ & $60^{\mathrm{a}}$ & 26 & 39 & 38 & 98.8 & 91.6 \\
\hline P. plecoglossicida ATCC $700383^{\mathrm{T}}$ & $63^{\mathrm{a}}$ & 27 & 39 & 45 & 99.7 & 94.2 \\
\hline P. putida IAM $1236^{\mathrm{T}}$ & $62^{\mathrm{a}}$ & 26 & 42 & 100 & 98.5 & 92.5 \\
\hline P. taiwanensis DSM $21245^{\mathrm{T}}$ & $63^{\mathrm{a}}$ & 36 & $51^{c}$ & $48^{\mathrm{c}}$ & 99.7 & 93.0 \\
\hline
\end{tabular}

a DNA G + C contents for other closely related Pseudomonas type strains were taken from Elomari et al. [4], Nishimori et al. [18], Uchino et al. [23], Dabboussi et al.[3] and

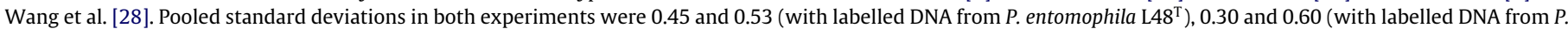
putida ${ }^{\mathrm{T}}$ ) and 0.30 (with labelled DNA from $P$. mosselii $^{\mathrm{T}}$ ).

b Reassociation values are means of two determinations.

c Reassociation values for $P$. taiwanensis DSM $21245^{\mathrm{T}}$ with labelled DNA from P. mosselii ${ }^{\mathrm{T}}$ and $P$. putida ${ }^{\mathrm{T}}$ were taken from Wang et al. [28]. 
Table 2

Differential phenotypic characteristics of Pseudomonas entomophila $\mathrm{L}^{\mathrm{T}}{ }^{\mathrm{T}}$ from related Pseudomonas type strains.

\begin{tabular}{|c|c|c|c|c|c|c|c|c|c|}
\hline \multirow[t]{2}{*}{ Characteristic } & \multicolumn{9}{|l|}{ Strains } \\
\hline & 1 & 2 & 3 & 4 & 5 & 6 & 7 & 8 & $9^{\mathrm{b}}$ \\
\hline Cell shape ${ }^{a}$ & Rod & Rod & Rod & Rod & Rod & Rod & Rod & Rod & Rod \\
\hline Motility $^{\mathrm{a}}$ & + & + & + & + & + & + & + & + & + \\
\hline Flagelation $^{\mathrm{a}}$ & $\begin{array}{l}\text { Single } \\
\text { polar }\end{array}$ & Polar & Polar & ND & $\begin{array}{l}\text { Single } \\
\text { polar }\end{array}$ & Polar & $\begin{array}{l}\text { Multiple } \\
\text { polar }\end{array}$ & Polar & $\begin{array}{l}\text { One or } \\
\text { three polar }\end{array}$ \\
\hline \multicolumn{10}{|l|}{ Fluorescent pigments } \\
\hline Pseudomonas Agar F & + & + & - & - & + & - & - & + & + \\
\hline Pseudomonas Agar P & - & - & - & - & - & - & - & - & - \\
\hline \multicolumn{10}{|l|}{ Growth at/on ${ }^{a}$} \\
\hline $5^{\circ} \mathrm{C}$ & + & + & + & + & + & + & + & + & + \\
\hline $42^{\circ} \mathrm{C}$ & + & - & - & - & - & - & - & - & + \\
\hline $\mathrm{pH} 4$ & - & - & - & - & + & - & - & - & + \\
\hline $6 \% \mathrm{NaCl}$ & + & + & + & + & + & + & - & - & + \\
\hline $7 \% \mathrm{NaCl}$ & - & + & + & - & - & + & - & - & - \\
\hline $8 \% \mathrm{NaCl}$ & - & - & + & - & - & - & - & - & - \\
\hline \multicolumn{10}{|l|}{ Activity of enzymes (API 20NE test) } \\
\hline Reduction of nitrate & - & - & - & - & - & - & + & - & - \\
\hline Presence of arginine dihydrolase & + & - & - & + & + & + & + & + & + \\
\hline Urease & - & - & - & - & + & - & - & - & - \\
\hline Hydrolysis of gelatin & + & - & - & - & + & - & - & - & - \\
\hline \multicolumn{10}{|l|}{ Growth on (API 20NE test) } \\
\hline Arabinose & - & - & - & + & - & - & - & - & + \\
\hline Mannose & + & - & - & - & + & + & - & - & - \\
\hline Manitol & + & - & - & - & + & - & - & - & - \\
\hline $\mathrm{N}$-acetyl-glucosamine & + & - & - & - & + & - & - & - & - \\
\hline Phenylacetic acid & + & - & - & + & + & + & + & + & + \\
\hline \multicolumn{10}{|l|}{ Carbon sources (Biolog GN2) } \\
\hline$\alpha$-Cyclodextrin & - & - & - & w & - & - & - & - & \\
\hline Dextrin & - & - & - & + & - & - & + & w & - \\
\hline Glycogen & w & + & $\mathrm{w}$ & + & - & + & + & + & - \\
\hline Tween 40 & + & + & + & + & + & + & - & + & - \\
\hline $\mathrm{N}$-acetyl-D-glucosamine & + & - & - & - & + & - & - & - & - \\
\hline Adonitol & - & - & - & - & - & + & - & - & - \\
\hline L-Arabinose & + & + & + & + & + & - & + & + & + \\
\hline D-Arabitol & + & - & - & - & + & - & - & - & - \\
\hline D-Cellobiose & - & - & w & - & - & - & + & - & - \\
\hline i-Erythritol & - & - & - & + & - & - & + & - & - \\
\hline D-Fructose & + & + & - & + & + & - & w & + & + \\
\hline L-Fucose & $\mathrm{w}$ & - & - & - & - & - & - & - & - \\
\hline$\alpha$-D-Glucose & + & + & + & - & + & + & + & + & + \\
\hline D-Mannitol & + & - & - & - & + & - & - & - & - \\
\hline D-Mannose & + & - & + & w & + & + & + & + & - \\
\hline D-Melibiose & - & - & $\mathrm{w}$ & + & - & - & + & + & - \\
\hline$\beta$-Methyl-D-glucoside & - & - & w & + & - & - & + & w & - \\
\hline D-Psicose & - & - & - & + & + & - & - & + & - \\
\hline D-Raffinose & - & - & - & - & - & - & w & - & - \\
\hline L-Rhamnose & - & - & - & w & - & - & + & - & - \\
\hline D-Sorbitol & - & - & - & - & - & - & + & - & - \\
\hline D-Trehalose & - & - & - & - & - & - & + & - & - \\
\hline Turanose & - & - & - & + & - & - & + & - & - \\
\hline Xylitol & - & - & - & - & - & - & w & - & - \\
\hline Mono-methyl-succinate & + & + & + & + & w & + & + & + & + \\
\hline Formic acid & + & + & - & + & + & + & + & + & - \\
\hline D-Galacturonic acid & - & - & - & + & - & - & - & + & + \\
\hline D-Glucosaminic acid & - & - & - & + & - & - & w & + & - \\
\hline D-Glucuronic acid & - & - & - & + & - & - & w & + & + \\
\hline$\alpha$-Hydroxy butyric acid & + & + & + & w & + & + & + & + & + \\
\hline$\gamma$-Hydroxy butyric acid & + & - & - & - & - & - & - & - & + \\
\hline p-Hydroxy phenylacetic acid & + & - & + & w & + & + & w & + & - \\
\hline Itaconic acid & - & - & + & w & - & - & + & + & - \\
\hline$\alpha$-Keto butyric acid & + & - & + & - & $\mathrm{w}$ & + & + & + & + \\
\hline$\alpha$-Keto valeric acid & + & - & - & w & + & + & + & + & + \\
\hline
\end{tabular}

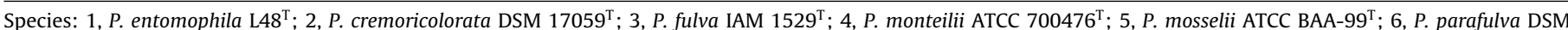

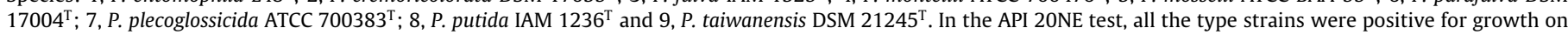

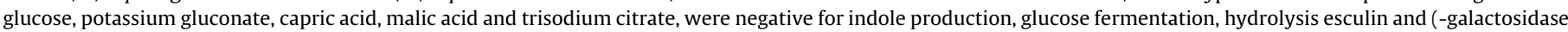

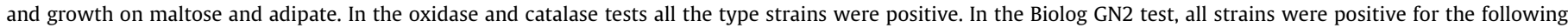

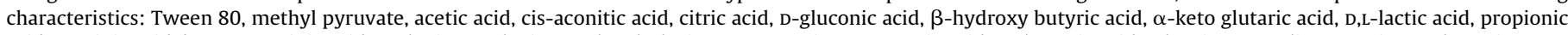

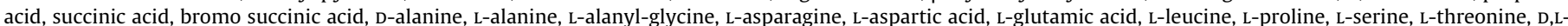

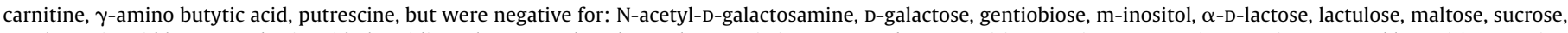

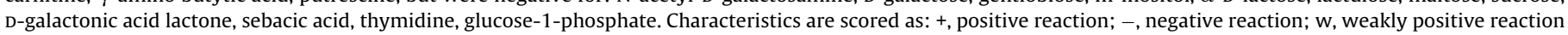
and ND, not determined.

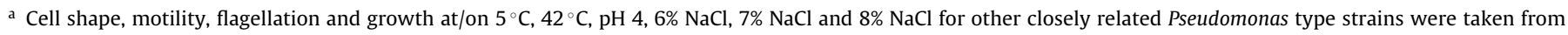
Elomari et al. [4], Nishimori et al. [18], Uchino et al. [23], Dabboussi et al. [3] and Wang et al. [28].

$\mathrm{b}$ The results of the API 20NE and Biolog GN2 tests for P. taiwanensis DSM 21245 ${ }^{\mathrm{T}}$ were taken from Wang et al. [28]. 
test was performed with the cytochrome oxidase test paper. The catalase activity was detected by adding $3 \%$ hydrogen peroxide solution to resting cells and examining the production of bubbles. Production of a fluorescent pigment was tested on King B medium (Pseudomonas agar F, Difco), and pyocyanin production was detected with King A medium (Pseudomonas agar P, Difco) [9]. Differential phenotypical characteristics are indicated in Table 2.

Additional physiological and biochemical characteristics were tested using API 20NE, (bioMérieux) and Biolog GN2 microplates (MicroLog System) according to the manufacturer's instructions. The results are shown in Table 2. API 20NE test results indicated that $P$. entomophila $\mathrm{L} 48^{\mathrm{T}}$ differed from $P$. mosselii ATCC BAA-99 ${ }^{\mathrm{T}}$ only in urease activity, which is negative for $P$. mosselii and positive for all other Pseudomonas of the group.

All type strains in the P. putida group were negative for gelatinase, manitol and $\mathrm{N}$-acetyl-glucosamine, with the exception of strain $\mathrm{L} 48^{\mathrm{T}}$ and $P$. mosselii ATCC BAA-99 ${ }^{\mathrm{T}}$. The API 20NE and Biolog tests indicated that $P$. entomophila $\mathrm{L}^{4} 8^{\mathrm{T}}$ was positive in the ability to use gamma-hydroxy butyric acid as a carbon source, whereas $P$. mosselli ATCC BAA- $99^{\mathrm{T}}$ was negative. $P$. entomophila $\mathrm{L} 48^{\mathrm{T}}$ was urease negative and did not use D-psicose as a carbon source, and $P$. mosselli was positive in both tests. As shown in Table 2, $P$. entomophila $\mathrm{L}_{4} 8^{\mathrm{T}}$ differed in three biochemical tests from $P$. mosselli and in more than nine with the other strains of the P. putida group. P. entomophila $\mathrm{L}^{\mathrm{T}} \mathrm{S}^{\mathrm{T}}$ also differed in 10 different phenotypic characteristics with Pseudomonas parafulva DSM $17004^{\mathrm{T}} ; 14$ with P. fulva IAM $1529^{\mathrm{T}}$, P. putida IAM $1236^{\mathrm{T}}$, Pseudomonas cremoricolorata DSM $17059^{\mathrm{T}}$ and $P$. taiwanensis DSM $21245^{\mathrm{T}}$; 19 with P. plecoglossicida ATCC $700383^{\mathrm{T}}$; and 20 with P. monteilli ATCC $700476^{\mathrm{T}}$.

To determine chemotaxonomical markers, a Matrix-Assisted Laser Desorption/Ionisation Time-of-Flight Mass Spectrometry (MALDI-TOF MS) analysis of $P$. entomophila $L 48^{\mathrm{T}}$ and its closely related type strains was performed at Anagnosteg $\mathrm{GmbH}$ (Germany) [8] as described by Scotta et al. [20]. The profile of peaks obtained for each species was analysed and compared using the software BGP database available at the website http://sourceforge.net/projects/bgp. A dendrogram was generated using the Permutmatrix programme, applying average linkage method (UPGMA hierarchical clustering) and Pearson's distance correlation [1]. The duplicate or quadruplicate whole cell spectra profiles for each strain analysed clustered at least with a $60 \%$ similarity. Spectra of two different type strains were less than $50 \%$ similar. In the MALDI-TOF MS analysis P. entomophila $\mathrm{L}^{2} 8^{\mathrm{T}}$ showed twenty-two single $\mathrm{m} / \mathrm{z}$ peaks (supermass values) not present in the other strains. These data further support the conclusion that $P$. entomophila strain $\mathrm{L} 48^{\mathrm{T}}$ is a distinct species and is separate from all other Pseudomonas species, even at the level of expression of the most abundant cellular proteins as shown in Supplementary Fig. S3.

Additionally, gas chromatography of cell fatty acids methyl esters composition (CFA) was determined at the CCUG (Culture collection, University of Göteborg, Sweden) using a standardized protocol, similar to that of the MIDI Scherlock MIS system (http://www.ccug.se/pages/CFAmethod2008.pdf). Major CFAs for strain $\mathrm{L}_{4}{ }^{\mathrm{T}}$ were $\mathrm{C} 16: 0$ (25.1\%), C16:1 w7c (14.7\%), C17:0 CYCLO (13.1\%); the summed feature 2 (C18:1 w7c/12t/9t; $12.2 \%), \mathrm{C} 10: 03-$ $\mathrm{OH}(9.4 \%), \mathrm{C} 12: 02-\mathrm{OH}(6.8 \%), \mathrm{C} 12: 03-\mathrm{OH}(5 \%)$; and the unidentified CFA with ECL 10.651 (4.4\%); all other detected CFAs values were less than $2.0 \%$. Comparative results for close related Pseudomonas type strains are given in Supplementary Table S5.

Considering the phylogenetic, chemotaxonomic, genomic and phenotypic characteristics, we propose $P$. entomophila strain $\mathrm{L}^{\mathrm{T}} 8^{\mathrm{T}}$ as the type strain of the new species Pseudomonas entomophila sp. nov.

\section{Formal description of Pseudomonas entomophila sp. nov.}

Pseudomonas entomophila (en.to.mo'.phi.la. Gr. n. entomon, insect; N.L. fem. adj. phila, from Gr. fem. adj. philê, loving; N.L. fem. adj. entomophila, insect loving, isolated from $D$. melanogaster).

Cells are Gram-negative rods that are $0.67-1.0 \mu \mathrm{m}$ wide and $2.2 \mu \mathrm{m}$ long and motile by means of one polar flagellum. Cells are catalase and oxidase positive, strictly aerobic and nonfermentative. After $16 \mathrm{~h}$ incubation at $30^{\circ} \mathrm{C}$ on LB agar, colonies are circular, beige in colour, flat, with regular edges and approximately 3-4 $\mathrm{mm}$ in diameter. Growth is observed in the presence of $0-6 \%(\mathrm{w} / \mathrm{v}) \mathrm{NaCl}$ (optimum at $2-3 \%$ ) and at $4-42{ }^{\circ} \mathrm{C}$ (optimum at $30-37^{\circ} \mathrm{C}$ ). The $\mathrm{pH}$ range is $5-9$. A fluorescent pigment is produced on Pseudomonas agar F, but no pyocyanin is produced on Pseudomonas agar $\mathrm{P}$. Biochemical tests and substrates utilized are given in diagnostic Table 2 . The DNA G + C content of the type strain as deduced from the whole chromosome sequence is $60 \mathrm{~mol} \%$. Strain $\mathrm{L}^{\mathrm{T}} 8^{\mathrm{T}}$ is entomopathogenic.

The type strain, $\mathrm{L}_{48}^{\mathrm{T}}\left(=\mathrm{CCUG} 61470^{\mathrm{T}}=\mathrm{CECT} 7985^{\mathrm{T}}\right)$, was isolated from D. melanogaster in Guadeloupe Island by Vodovar et al. [26].

\section{Acknowledgements}

We acknowledge the CCUG staff and specially K. Molin and E.R.B. Moore for the CFAs analyses and constructive discussions. This work was supported by projects CGL 2008-03242 from the CICYT (Spain), Consolider (CSD 2009-00006) and FEDER funding. $\mathrm{M}$. Gomila is the recipient of a postdoctoral contract from the Juan de la Cierva programme of the Ministerio de Ciencia e Innovación of Spain.

\section{Appendix A. Supplementary data}

Supplementary data associated with this article can be found, in the online version, at doi:10.1016/j.syapm.2011.12.003.

\section{References}

[1] Caraux, G., Pinloche, S. (2005) Permutmatrix: a graphical environment to arrange gene expression profiles in optimal linear order. Bioinformatics 21, 1280-1281.

[2] Cowan, S.T., Steel, K.J. (1974) Gram negative bacteria. In: Cowan, S.T. (Ed.), Manual for the Identification of Medical Bacteria, 2nd edition, Cambridge University Press, London, pp. 77-122.

[3] Dabboussi, F., Hamze, M., Singer, E., Geoffroy, V., Meyer, J.M., Izard, D. (2002) Pseudomonas mosselii sp. nov., a novel species isolated from clinical specimens. Int. J. Syst. Evol. Microbiol. 52, 363-376.

[4] Elomari, M., Coroler, L., Verhille, S., Izard, D., Leclerc, H. (1997) Pseudomonas monteilii sp. nov., isolated from clinical specimens. Int. J. Syst. Bacteriol. 47, 846-852.

[5] Felsenstein, J. (1981) Evolutionary trees from DNA sequences: a maximum likelihood approach. J. Mol. Evol. 17, 368-376.

[6] Goris, J., Konstantinidis, K.T., Klappenbach, J.A., Coenye, T., Vandamme, P. Tiedje, J.M. (2007) DNA-DNA hybridization values and their relationship to whole-genome sequence similarities. Int. J. Syst. Evol. Microbiol. 57, 81-91.

[7] Jukes, T., Cantor, C. (1969) Evolution of protein molecules. In: Munro, H.N. (Ed.), Mammalian Protein Metabolism, Academic Press, New York, pp. 21-132.

[8] Kallow, W., Erhard, M., Shah, H.N., Raptakis, E., Welker, M. (2010) MALDITOF MS for microbial identification: years of experimental development to an established protocol. In: Shah, H.N., Gharbia, S.E., Encheva, V. (Eds.), Mass Spectrometry for Microbial Proteomics, John Wiley \& Sons, London, pp. 255-277.

[9] King, E.O. (1954) Two simple media for the demonstration of pyocyanin and fluorescin. J. Lab. Clin. Med. 44, 301-307.

[10] Lalucat, J. (1988) Analysis of refractile (R) bodies, in: Mayer, EE. (Ed.), Methods in Microbiology-Electron Microscopy in Microbiology, vol. 20, Academic Press, London, pp. 79-90.

[11] Lane, D. (1991) 16S/23S sequencing. In: Stackebrandt, E.G., Goodfellow, M.M (Eds.), Nucleic Acids Techniques in Bacterial Systematics, John Willey, Chichester, pp. 115-175

[12] Lind, E., Ursing, J. (1986) Clinical strains of Enterobacter agglomerans (synonyms, Erwinia herbicola Erwinia milletiae) identified by DNA-DNA hybridization. Acta Pathol. Microbiol. Immunol. Scand. Sect. B 94, 205-213.

[13] Matthijs, S., Laus, G., Meyer, J.M., Abbaspour-Tehrani, K., Schafer, M., Budzikiewicz, H., Cornelis, P. (2009) Siderophore-mediated iron acquisition in 
the entomopathogenic bacterium Pseudomonas entomophila L48 and its close relative Pseudomonas putida KT2440. Biometals 22, 951-964.

[14] Mulet, M., Lalucat, J., García-Valdés, E. (2010) DNA sequence-based analysis of the Pseudomonas species. Environ. Microbiol. 12, 1513-1530.

[15] Mulet, M., Bennasar, A., Lalucat, J., García-Valdés, E. (2009) An rpoD-based PCR procedure for the identification of Pseudomonas species and for their detection in environmental samples. Mol. Cell. Probes 23, 140-147.

[16] Mulet, M., Gomila, M., Gruffaz, C., Meyer, J., Palleroni, N.J., Lalucat, J., GarciaValdes, E. (2008) Phylogenetic analysis and siderotyping as useful tools in the taxonomy of Pseudomonas stutzeri: description of a novel genomovar. Int. J. Syst. Evol. Microbiol. 58, 2309-2315.

[17] Nei, M., Kumar, S. 2000 Molecular Evolution and Phylogenetics, Oxford University Press, New York.

[18] Nishimori, E., Kita-Tsukamoto, K., Wakabayashi, H. (2000) Pseudomonas plecoglossicida sp. nov., the causative agent of bacterial haemorrhagic ascites of ayu Plecoglossus altivelis. Int. J. Syst. Evol. Microbiol. 50, 83-89.

[19] Santos, S.R., Ochman, H. (2004) Identification and phylogenetic sorting of bacterial lineages with universally conserved genes and proteins. Environ. Microbiol. 6, 754-759.

[20] Scotta, C., Bennasar, A., Moore, E.R.B., Lalucat, J., Gomila, M. (2011) Taxonomic characterisation of ceftazidime-resistant Brevundimonas isolates and description of Brevundimonas faecalis sp. nov. Syst. Appl. Microbiol. 34, 408-413.

[21] Tayeb, L.A., Ageron, E., Grimont, F., Grimont, P.A.D. (2005) Molecular phylogeny of the genus Pseudomonas based on rpoB sequences and application for the identification of isolates. Res. Microbiol. 156, 763-773.

[22] Tayeb, L.A., Lefevre, M., Passet, V., Diancourt, L., Brisse, S., Grimont, P.A.D. (2008) Comparative phylogenies of Burkholderia, Ralstonia, Comamonas Brevundimonas and related organisms derived from rpoB, gyrB and rrs gene sequences. Res. Microbiol. 159, 169-177.
[23] Uchino, M., Shida, O., Uchimura, T., Komagata, K. (2001) Recharacterization of Pseudomonas fulva Iizuka and Komagata 1963, and proposals of Pseudomonas parafulva sp. nov. and Pseudomonas cremoricolorata sp. nov. J. Gen. Appl. Microbiol. 47, 247-261.

[24] Vallet-Gely, I., Novikov, A., Augusto, L., Liehl, P., Bolbach, G., Péchy-Tarr, M., Cosson, P., Keel, C., Caroff, M., Lemaitre, B. (2010) Association of hemolytic activity of Pseudomonas entomophila, a versatile soil bacterium, with cyclic lipopeptide production. Appl. Environ. Microbiol. 76, 910-921.

[25] Veeranagouda, Y., Lee, K., Cho, A.R., Cho, K., Anderson, E.M., Lam, J.S. (2011) Ssg, a putative glycosyltransferase, functions in lipo- and exopolysaccharide biosynthesis and cell surface-related properties in Pseudomonas alkylphenolia. FEMS Microbiol. Lett. 315, 38-45.

[26] Vodovar, N., Vallenet, D., Cruveiller, S., Rouy, Z., Barbe, V., Acosta, C., Católico, L., Jubón, C., Lajas, A., Segurens, B., Vacherie, B., Wincker, P., Weissenbach, J., Lemaitre, B., Médigue, C., Boccard, F. (2006) Complete genome sequence of the entomopathogenic and metabolically versatile soil bacterium Pseudomonas entomophila. Nat. Biotechnol. 24, 673-679.

[27] Vodovar, N., Vinals, M., Liehl, P., Basset, A., Degrouard, J., Spellman, P., Boccard, F., Lemaitre, B. (2005) Drosophila host defense after oral infection by an entomopathogenic Pseudomonas species. Proc. Natl. Acad. Sci. USA 102, 11414-11419.

[28] Wang, L.-T., Tai, C.-J., Wu, Y.-C., Chen, Y.-B., Lee, F.L., Wang, S.-L. (2010) Pseudomonas taiwanensis sp. nov., isolated from soil. Int. J. Syst. Evol. Microbiol. 60, 2094-2098.

[29] Yamamoto, S., Kasai, H., Arnold, D.L., Jackson, R.W., Vivian, A., Harayama, S. (2000) Phylogeny of the genus Pseudomonas: intrageneric structure reconstructed from the nucleotide sequences of gyrB and $r p o D$ genes. Microbiology $146,2385-2394$.

[30] Ziemke, F., Hofle, M.G., Lalucat, J., Rosselló-Mora, R. (1998) Reclassification of Shewanella putrefaciens Owen's genomic group II as Shewanella baltica sp. nov. Int. J. Syst. Bacteriol. 48, 179-186. 